\title{
Antecedents And Consequences Of Foreign Direct Investment And International Procurement Through A General Strategic Management Lens
}

Virginia Anne Taylor, (E-mail: taylorv@wpunj.edu), William Paterson University

\begin{abstract}
Since multiple perspectives and dynamic national environments can be applied to explain how value is created in an international context, multinational firms need analytical guidelines when facing procurement and production decisions concerning various worldwide locations for valueadded chain activities such as marketing, production, distribution, and after sales service. The ultimate aim of this research was to abstract and empirically test a realistic but fairly simple localization framework to facilitate the design of an information system that supports a cost-benefit analysis based on legal requirements, value chain activities, and product costs. A balance was sought between inclusiveness and minimalism in the development of a normative model for implementation of dynamic strategic planning and control programs. The data show the participants' behavior is significantly influenced by all three elements supporting the value-added localization model and validating the holistic approach put forth by Lecraw \& Morrison (1991).
\end{abstract}

\section{Introduction}<smiles>CC1CCCCC1</smiles>

$\mathrm{n}$ the $21^{\text {st }}$ century globalized markets, international foreign direct investment, and worldwide procurement combine to create a complex and dynamic business decision-making environment. In this paper the antecedents and consequences of foreign direct investment $\&$ international procurement are investigated using a value-added concept, which measures the consequences of localized business activity. This means the expected outcomes are viewed as the creation (destruction) of value. The first part of this research explores the cross-disciplinary nature of the antecedents to foreign direct investment and foreign procurement. Strategic management and economic perspectives are considered. The second part develops a model to analyze the global and local consequences and their effects on future decision-making. Finally the model depicting the interactive nature of the antecedents and consequences of multinational activity and government policy is empirically tested with survey data from foreign firms operating in the USA.

The complicated nature of worldwide business transactions makes analytical decision support absolutely essential to allow increasingly powerful information technology to process the enormous volume of data generated by global operations. Due to the complexity of today's work world, traditional theories from the management or economics disciplines may prove individually inadequate as the basis for executive decisions. With dramatic changes occurring nationally and globally, corporate decision-makers must look at the foreign direct investment and procurement processes very thoroughly. Analytical models are needed to bring order, structure, and organization to this data and thereby improve the effectiveness and optimality of these decisions. The general purpose of this study is to analyze the determinants of localization. The specific research objectives are to identify the underlying reasons for multinational enterprises' decisions to localize business activity, to develop an interdisciplinary model to analyze the antecedents and consequences of these decisions, and finally to test the model. The initial focus is on

Readers with comments or questions are encouraged to contact the author via email. 
the relationship between environmental dynamism and decisions to localize value-added activity. The next section examines the reasons for foreign direct investment and international procurement through a transnational strategic management lens. The final dimension looks at economic factor endowments and public policy considerations. A value creation framework facilitates comparison of multiple perspectives within a dynamic global environment.

\section{Literature Review}

This review of the literature examines environmental dynamics and the general strategic management perspective on localization and then considers complexity issues from an economic policy perspective. Three general propositions, each representing a variable element of the interdisciplinary model that follows later in the paper, were drawn from the literature. Accordingly, each proposition is positioned as an introduction to the appropriate literature. Throughout the literature review, application of the elements to factual settings is included to exemplify the various dimensions of the proposed framework by using the case study approach.

\section{Proposition 1: Environmental dynamics influences localization decisions}

The environmental dynamics that result from inter-organizational relationships within the general environment have great research potential (Hall, 1987). Literature on the interactive nature of the organization-environment interface draws on a rich theoretical basis from finance, economics, strategic management, and organizational behavior. Certain commonalities exist in the industrial organization economics and strategic management theory. For example, there is a general belief that both government and business policy is shaped by constituent, external, politi$\mathrm{cal}$, and economic pressures and that the determination of relative causality is complicated by the endogenaity of relationships. Emery and Trist (1965) and Aldrich (1979) found that organizational boundaries are permeable in nature and responsive to contextual operating environments. Dess and Beard (1984) refined Aldrich's six dimensions of environmental context to three: complexity, munificence or richness, and dynamism often used in management and organizational theory textbooks (Jones, 2001) to explain the concept of uncertainty. Michael Porter's (1990) analysis tools include a "five forces" framework to study the industry environment and a "national diamond" to investigate country environments. His theory notes the expansion of local supplier bases to meet increased demand for intermediate goods. In the USA clusters of related auto industries have developed in North Carolina, which has become home to 185 foreign owned companies (Barnet \& Cavanaugh, 1994). Global corporate actors have many roles in the world economy; as producers, investors, innovators, and traders they make decisions that change the competitive environment (Root, 1994). For example, when the Common Market challenged multinational firms' market share in Europe, many American firms flocked to produce inside the tariff wall. Foreign direct investment replaced American exports; as a result by 1972 the USA had a trade deficit (Root, 1994). In the Pacific Rim foreign direct investment spawned an economic growth cycle where new job creation and enhanced worker skills generated an emerging consumer class with seemingly insatiable market demand (Engardio \& Roberts, 1996). This led leading firms like INCO to capitalize on the growth by investing in new Asian production facilities (Hand, 1995). Environmental munificence decreases and complexity increases when multiple actors compete in the same environment. These interactions cause contextual change; the nature of the environment becomes dynamic. Literature supports the proposition \#1, environmental dynamics influence decisions to localize value-added activity.

\section{Proposition 2: Transnational management strategy influences localization decisions.}

Management theorists posit that environmental conditions shape strategy through incentives; but, firms retain the critical role and choose which local environmental advantages to exploit (Child, 1972). Morrison and Roth (1992) present evidence that significant discretionary differences exist between firms within the same global industry. Despite common threats from the external environment, firms exercise considerable discretion in how to meet the basic requirements of the market served. When faced with uncertainty due to scarcity firms may chose a niche strategy to reduce the scope of resource dependence. Backward vertical integration is an alternate solution to resource uncertainty (Buckley \& Casson, 1988; Tallman \& Shenkar, 1994). Modern day strategic alliances cloud the issue further (Doz \& Phahalad, 1989). Japanese and Korean industrial group often make boundaries ambiguous; power and influence are often invisible. These unique strategic responses exploit learned routines (Kogut \& Zander 1993) and experience in government relationships (Chandler 1991) to create competitive advantage. The primary 
advantage of a transnational organization lies in the flexibility to transfer resources across national borders through a globally maximizing network. (Ghoshal \& Bartlett, 1990; Kogut, 1985b; Doz \& Prahlad, 1981, 1984; Mitchell, 1992). International business research articulates the need for strategic objectives and investment to accommodate the political policies that originate in various host countries (Morrison \& Inkpen, 1991). As suggested by (Itaki, 1991), this analysis co-considers trade and foreign direct investment theory. Analyses of the socio-economic conditions that support increased localization are part of the control and strategy implementation processes (Preble, 1992; Schreyogg \& Steinmann, 1987; Gates \& Egelhoff; Doz \& Prahalad, 1984). Responsiveness to economic and political environment has been addressed in Strategic Management Journal (Rumelt, Schendel, \& Teece, 1991; Chandler and Nelson, 1991) and international management textbooks (Phatak, 1992; Marcus, 1996). Analysis of political risk (Simon, 1984; Boddewyn, 1985) financial risk (Choi, 1972; Levi, 1983) and diversification benefits (Rumelt, 1974; Morck \& Yeung, 1991; Kim Hwang \& Berger, 1993) are used to evaluate investment and procurement decisions. Resource dependence scholars (Hall, 1987; Hannan \& Freeman, 1977; Pfeffer \& Salancik, 1978) focus more heavily on the nature and distribution of resources in the environment. The management literature suggests corporate strategic objectives influence decisions to invest in localized production facilities and engage in local procurement.

\section{Proposition 3: Economic and political variables influence localization decisions.}

Economists suggest that from a global viewpoint, trade and foreign direct investment restrictions are not beneficial to the world at large; but governments may sub-optimize world economic growth for national interests. There is ample evidence that activist government industrial policies try to maximize national welfare. Gordon and Lees characterize the competitive rivalry among nations for industrial power and market share as a "struggle for industrial supremacy" (Gordon \& Lees, 1986 p. 6). Policy tools include subsidies, export taxes, import tariffs, quotas, voluntary export restraints, and local content requirements. The policy mix is not the same at all times and in all places; it depends on history, market structure, and current circumstances. It is clear that individual governments have strong incentives to attract foreign direct investment and local procurement to enhance economic growth (Lecraw \& Morrison, 1991). These same governments also want to regulate corporate activities thereby curtailing the power of transnational corporations (Tyson, 1995). Economic policy researchers have often judged the desirability of localization from its contribution to full and stable employment (Mohn, 1992; Tyson, 1995; King, 1995) and equitable income distribution among workers of the world. Nations craft international policy and organizations develop strategies to manage their access to scarce resources. INCO Ltd. built a production facility in China to capitalize on the characteristics of munificence, abundant labor, and huge market potential. However, national government policy introduced complexity and influenced the choice of joint-venture entry mode for this nickel salts plant (Hand, 1995). China restricts foreign investment; manufacturers vie for limited joint ventures and must create local content (Johnson, 1994). Siemens, convinced that firms with "deep roots in local markets will continue to prosper", invested over \$200 million in training and manufacturing facilities across the USA (Langer \& Hoser, 1995). National requirements for localization affect competitive issues in both domestic and international arenas. Belgium's investment aid programs are linked to job creation (Gordon, 1991).

Classic economic writers, taking an international or worldwide perspective, have focused more on the efficient resource allocation and technological progress (McCulloch, 1985). Localization requirements are viewed as trade restrictions which distort trade, stifle competition, raise prices, and generate monopoly rents (Lindert, 1991; Root, 1994). Oligopolistic structure, segmented markets, and entry barriers in some industries make pure competition and marginal cost pricing unrealistic assumptions (Scherer \& Ross, 1990; Deutch, 1993). As firms seek to minimize transaction costs (Williamson, 1975) these industrial sector environmental realities strongly influence both the corporate strategic decisions and government policy outcomes (Chandler, 1992; Gorden, 1991). Government action can be a catalyst. Prior to 1989 semiconductors assembled in the EC were deemed to have EC origin and avoided a $14 \%$ tariff. A sudden rule change now requires the process of diffusion be local for EC origin. US companies now have 40 fabrication facilities in Europe. Prior to the new rule most American firms performed this process in the USA (Jensen-Moran, 1996). Diminished intermediate goods supplier bases curtail critical interaction between domestic firms; a country can experience hallowing out of a domestic industry. Literature suggests economic and political variables influence localization decisions.

Figure 1. Propositions explaining why firms invest in local production and procurement 


\section{Transnational Management $\rightarrow$}

3. Economics \& Politics $\rightarrow$
To Localize Value-

Added Activity

\section{Theoretical Foundation for a Value-Added Model}

As multinational firms seek to acquire scarce resources from munificient world environments, geographic factor differences and government policies cause contextual complexity while multiple interactions among firms and governments create a dynamic environmental texture. This research methodology uses value-creation as the utility or unity factor to explain localization decisions. Roget, (1979) says that value connotes utility, benefit, goodness, importance, and significance. Thus value may have tangible, intangible, and inter-temporal aspects. National security, net present value of future cash flows, the potential earning power of education, the productivity possibilities of capital equipment, the spillover benefits, market potential of a large or rich population are examples of value. National governments evaluate the desirability of localization requirements and incentives using a cost-benefit analysis (Root, 1993) with an eye to domestic welfare (Gordon \& Lees 1986) and the next election. In 1996 the USA unilaterally changed the rules that determine where imported clothing or fabric originates. Facing reelection "President Clinton clearly wanted to cultivate the southern states which have a large textile industry" (Asia Week, 1996). Many management scholars have examined the concept of value creation as a value chain to justify the dispersion of these activities around the world (Porter, 1990, 1986; Roth \& Morrison, 1992; Yip, 1989). A value creation framework allows one to examine whether or not increased localization is desirable (adds value) from a strategic management or government point of view. This type cost-benefit analysis has been applied to local content requirements (Lecraw \& Morrison, 1991; Taylor, 1997) and foreign direct investment in less developed countries (Root, 1994). The literature suggests perspectives on value creation differ between and among strategic management executives and economic policy makers. Each group has their own agenda. Accordingly each views the expected consequences of localized business transactions with a different lens.

Reactions to a wide range of trade policies are a function of strategic objectives (Brewer, 1993; Rolfe, 1993). The dynamic in the political, economic, and competitive industrial environments are represented by the environmental dynamics, ED, within which governments and transnational managers operate. This model uses the concept of value to accommodate diverse perspectives. Business executives tend to define value creation as profit maximization. Transnational management's value, TM, represents the maximization of long and short term profits to create shareholder value as depicted in Figure 2. On the other hand economic policy makers are politicians who define value creation in terms of domestic welfare with an eye on the next election. Economic policy value, EP, is the maximization of domestic welfare. This local value-added concept measures the expected consequences of localized business activity. In other words the outcomes are described as the creation (destruction) of value. These expected consequences are the antecedents of the foreign direct investment and international procurement decisions to increase (decrease) the localization of value-added activity. The crossover model illustrated in Figure 2 suggests the actual localization process occurs in situations where the two perceptions of value overlap. In other words when the local government feels the proposed foreign direct investment will increase local domestic welfare and the corporation's executives believe the action will enhance current profitability, or future cash flows via increased market share, a crossover in perceptions of value creation occurs and localization activity takes place. 


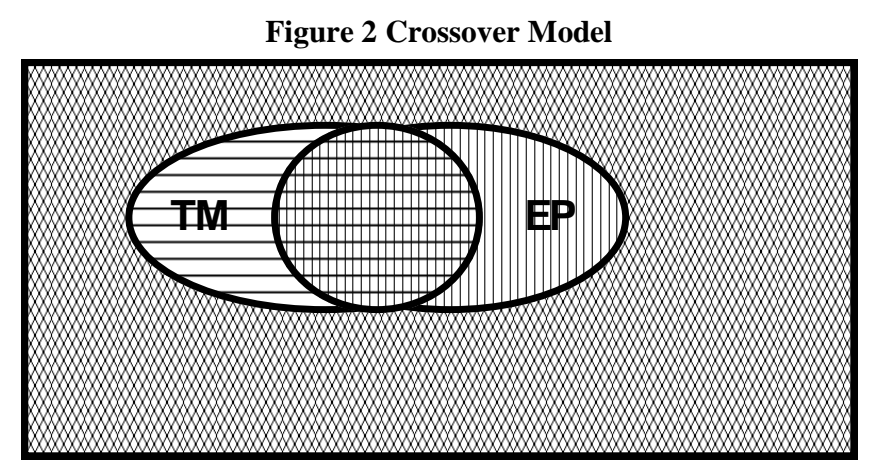

Governments and multinational firms, each shaping the destiny of the other, experience a crossover in value creation as they pursue their individual goals and stakeholders' interests. Analysis and decisions on both sides involve iterative competitive processes that occur in a dynamic world environment. Morning after effects occur on both the management and economic policy sides. Environmental dynamics are inevitable and will influence the value of localization and future decisions. For example, trade remediaries such as anti-dumping duties or more active enforcement of tariff, quota and anti-trust laws may encourage higher local content over time (Broeman, 1991; Root, 1994). China's government has indicated that $40 \%$ local content requirement will not be sufficient for cars manufactured after the year 2000. Companies wishing to do business in this major emerging market are required to provide research facilities and local parts factories in addition to joint venture assembly plants (Engardio \& Roberts, 1966). Environmental dynamics can originate within or between corporations and host governments or emanate from the worldwide environment. The establishment of local content, a value crossover between one government and a particular corporation, has global implications for the others. In a continually evolving environment competitive interaction takes place between firms and nations and the best value for each is relative to the alternative choices available at the time. Factors such as compatible resource bundles, the possibility of improved domestic welfare, profit potential and the decision process combine with precipitating circumstances. One theme that consistently emerges from foreign direct investment studies is that decisions focus on broad spectrum of conditions (Dunning, 1998, 1988; Brewer, 1993; Rugman, 1990) which include market factors, political conditions (Kobrin, 1991; Luger, 1988; Lee 1987), and the desire to minimize production cost (Porter, 1991; Kobrin, 1991; Jones,2001) and historical factors such as the "beachhead effect". Causality for localization is complicated by the endogenaity of these relationships as benefit seeking interactions lead to worldwide marketplace dynamics. Between 1991 and 1993 Siemens increased its US local content as a percentage of sales from $73 \%$ to $82 \%$ (Langer and Hoser, 1995). Externalities changed; proximity fostered interaction between firm's, suppliers, and customers. As nation states strengthen their economic ties on a regional basis, local content regulations and rules of origin become important to ensure that outsiders cannot take advantage of negotiated tariff reductions (Jensen-\& Moran, 1996).

\section{Research Method}

The first stage of this research examined the literature to explain how local content creates value and why firms localize production and procurement. Since the concept of value is complex with tangible and intangible aspects, the survey used two local content measures. The local content importance (LCi) variable represents the intangible goodness, utility, significance and benefit aspects of local content and the local content percent (LCp) variable measures the degree of US inputs. To investigate the underlying reasons for variation in the value set upon local content, the model incorporated three concepts, transnational management (TM), economic policy (EP) and environment dynamics (ED). They represent the three propositions derived from the literature review and reflect the dual character and co-determination of local content value as a function of business profits and domestic welfare. Accordingly, a series of twelve questions addressing suitable situational factors based on each of these variables was developed. Executives are asked to rate the impact of situational factors described in each statement with regard to USA local content decisions regarding the expenditures or re-evaluation of prior local investment. Respondents assigned scores to rank or measure the degree of importance by checking off answers on a scale ranging from a low of 1 to a high of 4 . To assure content validity experts in the field reviewed survey questions prior to mailing. Questions 
with problems were revised or eliminated. Multiple items and comparison of sub-sample results were used to enhance reliability. The survey was mailed to the chief executives listed in the 1995 edition of the Directory of Foreign Firms Operating in the United States (World Trade Academy, 1995). All firms indicating discrete products were contacted.

\section{Survey Results}

The evidence supports the general model and indicates the influence of strategic management, economicpolicy, and environmental dynamics on decisions about the localization of value-added activity. A discussion of the more important determinants and measures of individual item importance follows. The formation of trade blocks, and fluctuation in exchange rates, were rated as the most important world environmental dynamics factors. Changes in tariffs, quotas, and local sentiment were next. In assessing the total impact on localization attributed to general strategic management factors, the importance of USA sales as a percent of total revenue and the need to locate service facilities close to their customers were reported most frequently and rated as more important among the management items. Next in rank order was the image of good corporate citizen, a desire to keep core competence at headquarters and managing foreign exchange risk. Based on aggregate scores, the economic-political results reinforce the idea that marketing goals drive local content up in substance and value. The potential offered by the sheer size of the US market ranked first in this group, well ahead of cheaper raw materials. Host factor endowments were the primary reasons cited while political considerations were not rated important for US local content. Although primarily market driven, opinions do differ between high versus low local content groups. Both cite the size and importance of the US market. However, executives reporting high percentages of US local content also placed significantly more intangible value on maintaining the image of a good corporate citizen than did those reporting lower local content. They also indicated more strongly that a change in their political support base would be a reason to change the extent of local content in their product.

\section{Concluding Remarks}

It is vital for multinational enterprises to understand the value creation process from the host country perspective in order to operate comfortably within the socio-economic environments. A shared definition set will facilitate the design of information systems enabling management to calculate the projected value of local content for a country or region in order to meet anticipated legal requirements, coordinate value chain activities and minimize product costs. The caliber of these respondents adds considerable weight to the importance of these findings. They represent the high levels of strategic planners who have decided where the firms will configure the value chain and disperse the enormous resources of these economic giants around the world. National defense needs an industrial base with domestic capacity in key industries in order to meet military surge demand (Gordon \& Lees, 1986). Both Boeing and McDonnell Douglas have shifted aerospace R\&D and production to China causing US layoffs (Engardio \& Roberts, 1996) and possibly damaging future capacity in the USA for critical local content. Understanding how transnational corporations think is of utmost importance in the development and administration of effective government policy focused on increasing domestic welfare. There is clear evidence that the issue of localization of value added activity by multinationals is a vital component for competition among nations around the world. The model presented and the research it is based upon provide a framework to examine and monitor local content activity from multiple perspectives in a variety of circumstances. Knowledge is a competitive weapon. Developing peripheral vision, incorporating even the unarticulated needs and desires of multiple stakeholders on the economic terrain, and incorporating the intangible elements of value in the decision process will result in the creation of greater value.

\section{References}

1. Aldrich, H. 1979, Organizations and Environments. Englewood Cliffs: Prentice Hall

2. Asia Week, unknown author. (1996 11/19). Tussle over garments: America's new textile rules pose a daunting test to Asian exporters.

3. Barnet, R.J. \& J. Cavanagh. 1994, Global dreams: Imperial corporations and the new world order. NY: Simon \& Schuster.

4. Boddewyn, J., 1985, Theories of foreign direct investment and divestment: A classificatory note, Manage- 
ment International Review 25:1, 57-65.

5. Brewer, T. 1993, Government policies, market imperfections and foreign direct investment. Journal of International Business Studies, 24, 101-120.

6. Broeman, P.1991 Ed. New Jersey: A basic legal guide for foreign business, New Jersey State Bar Association.

7. Buckley, P. \& M. Casson. 1988, A theory of cooperation in international business. Management International Review, 28, 19-38.

8. Chandler, A.1991, The functions of the headquarters unit in the multi business firm. Strategic Management Journal, 12, 31-51.

9. Child, J. 1972, Organizational structure, environment, and performance: The role of strategic choice. Sociology, 6:1, 1-22.

10. Choi, J., 1972, Diversification, exchange risk and corporate international investment, Journal of International Business Studies.

11. Deutch, L., 1993, Industry studies, Englewood Cliffs: Prentice Hall.

12. Dess, G. and D. Beard 1984, Dimensions of organizational task environments, Administrative Science Quarterly, 29, 52-73.

13. Doz, V. \& C.K. Prahalad 1981, Head-quarters influence and strategic control in MNCs. Sloan Management Review, 23: 1, 15-29.

14. Dunning, J. 1988, The eclectic paradigm of international production: A restatement and some possible extensions. Journal of International Business Studies, 19: 3, 1-31.

$15 . \quad 1998$.

16. Emery, F. and E. Trist, 1965, The causal texture of organizational environments, Human Relations, 18:1, 21-32.

17. Gates, S. and W. Egelhoff, 1986, Centralization in headquarters-subsidiary relationships, Journal of International Business Studies.

18. Ghoshal, S. \& C. Bartlett. 1990, The multinational corporation as an inter-organizational network. Academy of Management Review, 15:4, 603-625.

19. Gordon, S. \& F. Lees. 1986, Foreign multinational investment in the United States: Struggle for industrial supremacy. New York: Quorum Books.

20. Gordon, G. 1991, Industry determinants of organizational culture. Academy of Management Review, 16:2, 396-414.

21. Itaki, M., 1991, "A critical assessment of the eclectic theory of the multinational enterprize", Journal of International Business Studies, 22, 445-460.

22. Hall, R., 1987, Organizations, structures, processes \& outcomes, Englewood Cliffs, NJ: Prentice Hall

23. Hand, S., 1995, "Message to shareholders" Annual Report. INCO Ltd: Toronto.

24. Hannan, M. and J. Freeman, 1977, "The population ecology of organizations", American Journal of Sociology, 82:5, 929-964.

25. Jensen-Moran, J. 1996, "The coming rules of origin debate". The Washington Quarterly 19: 4, 239-253.

26. Johnson, C. with L. Tyson \& J. Zysman. (1989). Politics and productivity: The real story of why Japan works. Cambridge: Ballinger Publishing Co.

27. Jones, G.R. 2001 Organizational Theory. Upper Saddle River: Prentice Hall.

28. Kim, C.W., with P. Hwang and W. Bergers, 1993, Multinationals diversification and the risk-return tradeoff, Strategic Management Journal 14,275-286.

29. King, P., 1995, International Economics and international economic policy: A policy reader NY: McGraw Hill.

30. Kogut, B. 1985, Designing global strategies: Comparative and competitive value added chains. Sloan Management Review, 26:4, 15-28.

31. 1985b, Designing global strategies: Profiting from operational flexibility. Sloan Management Review, 27:1, 27-37.

32. Kogut, B. \& U. Zander. 1993, Knowledge of the firm and the evolutionary theory of the multinational corporation. Journal of International Business Studies, 24, 625-45.

33. Langer, H. and A. Hoser. 1995. A Review of Siemens Businesses in the USA. New York: Siemens Corporation. 
34. Lecraw, D. and A. J.Morrison. 1991. Transnational corporations-host country relations: A framework for analysis. Essays in International Business \#9. September. University of South Carolina: CIBER.

35. Lee, C. H. (1987). Foreign Lobbying in American Politics. Dissertation Abstracts International, 48, 2443A.

36. Levi, M., 1983, International Finance, New York: McGraw Hill.

37. Lindert, P. 1991, International Economics. Homewood, IL Irwin.

38. Luger, S. (1988). Private power, public policy, and the United States Automobile Industry. Dissertation Abstracts International, 50, 1423A.

39. Malkin, E. \& R. Neff. 1994, 11/28, The Japanese have a yen for Mexico again. Business Week. AOL.

40. Marcus, A. 1996, Business and Society: Strategy, ethics and the global economy, $2^{\text {nd }}$ Ed, Boston: Irwin.

41. McCulloch, Rachael. 1985, Point of view: Trade deficits, industrial competitiveness, and The Japanese. California Management Review, XXVII, 140 - 156.

42. Mitchell, W with J.M.Shaver and B. Yeung, 1992 Getting there in a global industry: Impacts on performance of changing international presence, Strategic Management Journal 1992.

43. Mohn, I., 1992, United States exports with a Japanese label: Potential effects of EC ' 92 on automobiles manufactured by Japanese companies on US soil, George Washington Journal Of International Law and Economics, 24.623-645.

44. Mork, R. and B. \& Yeung, Whey investors value multinational, 64, 165-187.

45. Morrison, A. and A. Inkpen, 1991, An analysis of significant contributions to the international business literature, Journal of International Business Studies, 22, 143-153.

46. Morrison, A. J. \& K. Roth. 1992, A taxonomy of business level strategies in global industries. Strategic Management Journal, 13,399 - 418.

47. Pfeffer. J., and G. R. Salancik. 1978. The External Control of Organizations. New York: Harper \& Row

48. Phatak, A., 1992, International Dimensions of Management, Boston: PWS Kent.

49. Porter, M. (1990). The competitive advantage of nations. New York: The Free Press.

50. Preble, J., 1992, Towards a comprehensive system of strategic control, Journal of Management Studies, 29, 391-404.

51. Rolfe, R. J. et al. (1993). Determinants of FDI incentive preferences of MNE's. Journal of International Business Studies, 24, 335-355.

52. Roth, K. an A. Morrison, 1992, Implementing global strategy; characteristics of global subsidiary mandates. Jourrnal of International Business Studies, 23, 715-735.

53. Root, F. R. 1994, International trade and investment 2 (7th ed.). Cincinnati, OH: South-Western Publishing.

54. Rumelt, R., 1974, Strategy, structure and economic performance, Boston: Harvard Business School.

55. Rumelt, R. with D. Schemdel and D. Teece, 1991, Strategic management and economics, Strategic Management Journal: 12, 5-29.

56. Scherer, F.M. \& D. Ross. 1990, Industrial market structure and economic performance. (3rd. ed.). Boston, MA: Houghton-Miffen.

57. Schreogg, G. and H. Steinmann, 1987, Strategic control: A new perspective, Academy of Management 12:1,91-103.

58. Simon, T., 1984, A theoretical perspective on political risk, Journal of International Business Studies 1 5:2, 123-142.

59. Tallman, S. B. \& O. Shenkar. 1994, A managerial decision model of international cooperative venture formation. Journal of International Business Studies, 25: 1, 92-113.

60. Taylor, V., 1997, Determinants of Local Content Value, Philadelphia: Temple University Dissertation

61. Tyson, L. D. 1995, Managed trade: Making the best of second best. in Philip King (ed.), International economics and international policy. New York: McGraw-Hill. 129-157.

62. Tallman, S. and O. Shenkar, 1994, A managerial decision model of international cooperative venture formulation, Journal of International Business Studies, 25:1, 92-113.

63. Williamson, O. 1975. Markets and Hierarchies. New York: The Free Press.

64. World Trade Academy 1995, Directory of foreign firms operating in the United States, $8^{\text {th }}$ ed. New York: World Trade Academy Press. 